\title{
Cave mining design methodology for use in challenging geomechanics environments
}

\author{
GA Ferguson Seltrust Associates Limited, UK \\ M Didyk Independent Mining Consultant, Chile \\ LF Zenteno Codelco, Chile \\ JF San Martin Codelco, Chile \\ RJ Fowell Leeds University, UK
}

\begin{abstract}
Underground cave mining design tends to rely upon empirical and numerical models, neither of which are able to close the engineering design loop. Such circumstances, mean that it is very difficult to analyse with certainty, the causes of significant problems that can arise from time to time. Widespread collapses and damaging mining-induced seismicity, have occurred, for example, within the El Teniente mine, and are examples of cave mining problems that appear to have been without resolution. Further, fundamental and relevant engineering design issues tend to be lost in a swathe of other issues, which have only minor importance, in comparison to the major concern in cave mining - that of long-term stability and productivity of the production complex. Cave mining design methodology put forward in this paper is based upon the fundamental precepts that: a detailed and in-depth knowledge and understanding of the geomechanics mechanisms involved in the response of the rock mass to the creation of excavations by mining is essential, selection of alternative design components is based upon quantitative risk analyses integrated within project cash flows, and successful implementation of mining designs requires that operators follow method-specific mining tactics. Practical examples are outlined to illustrate the process.
\end{abstract}

Keywords: cave mining design, geomechanics in mine planning, risk-based decision-making

\section{Introduction}

Underground cave mining is generally regarded as a low cost method for the extraction of large-scale mineral resources. This assumption may well have been true of cave mining in weak rock masses relatively close to surface, where the rock mass is readily caved, and blasting activities were kept to a minimum. However, today, cave mining operations are expected to extract hard rock at considerable depth below surface. Consequently, cave mines can suffer significant problems and operational hazards, which affect the expected outcome with respect to costs and the regular flow of minerals delivered to the plant.

The main engineering problem is that mines implementing cave mining and other mining methods, do not have the luxury of working in a geological environment which they control. In particular, the magnitude and direction of in situ field stresses are difficult to measure with accuracy, and the rock mass strength cannot be directly measured for use in engineering design and subsequent monitoring programs. From an engineering design viewpoint, such circumstances make the attainment of knowledge to advance the evolution of a mining design process difficult. Box, based upon many years' experience of the statistical analysis of experimental work, declared that "the attainment of knowledge is an endless spiral proceeding alternately from deduction to induction and back" (Box 1979). Current and historical practice to undertake cave mining design (April 2017), is to replicate caving designs applied previously in the mine in question, and, sometimes, to incorporate experiences from other mining districts. Such designs are supported in a technical sense by so called calibrated state-of-the-art numerical models and empirical-based designs. 
Ideally, it should be possible to construct models based upon rock mass properties measured in situ and the environment (stress field) in which cave mining takes place and utilise models to design, predict and manage future outcomes. However, this suggests that the key parameters have been identified and that their values are known with a certain degree of confidence. Prediction might then be performed with some certainty, a pressing industrial requirement, given the need for high levels of safety and the significant sums of money involved in constructing a new cave mine. It is a logical conclusion therefore, that engineering work should be formally structured upon the need to work with models and to improve them as they are applied, so demanding field observations and measurements, aligned to the overall cave mining and design engineering methodology, to:

- Declare design objectives.

- Engineer and select an appropriate design from alternatives.

- Implement the selected alternative.

- Monitor performance of the implementation of the selected alternative.

- Deduce lessons from the analysis of measurements (and observations).

- Apply lessons to the design, engineering, project implementation and associated operations.

\section{Objectives-based cave mining design}

Objectives-based engineering provides guidance and technical support for the design and selection of the many components encountered in cave mining design (Ferguson 2015). Whilst the major engineering disciplines civil, mechanical and electrical, have established codes of practice, the mining industry lacks a universal code of practice to bring together and consider the geological, geomechanical and practical issues in a logical and technically supported design.

\section{$2.1 \quad$ Engineering design}

Two phases, engineering design (Figure 1), followed by implementation (Figure 2), characterise the methodology.

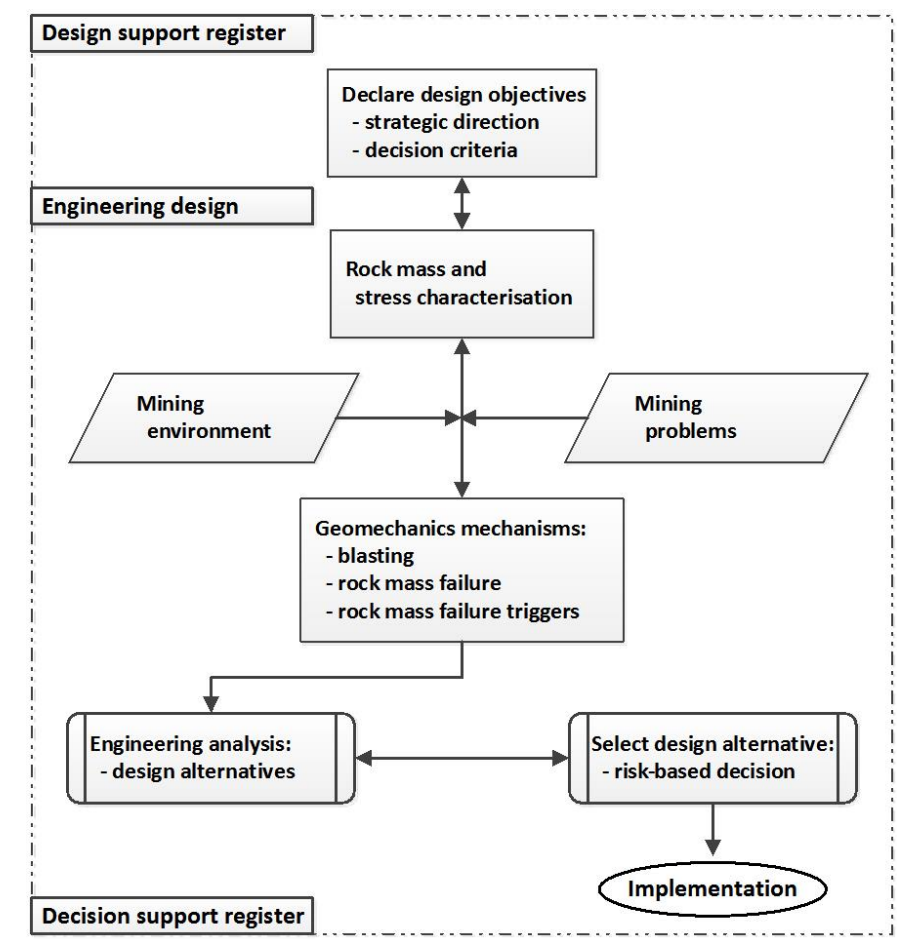

Figure 1 Objectives-based cave mining design - engineering phase 


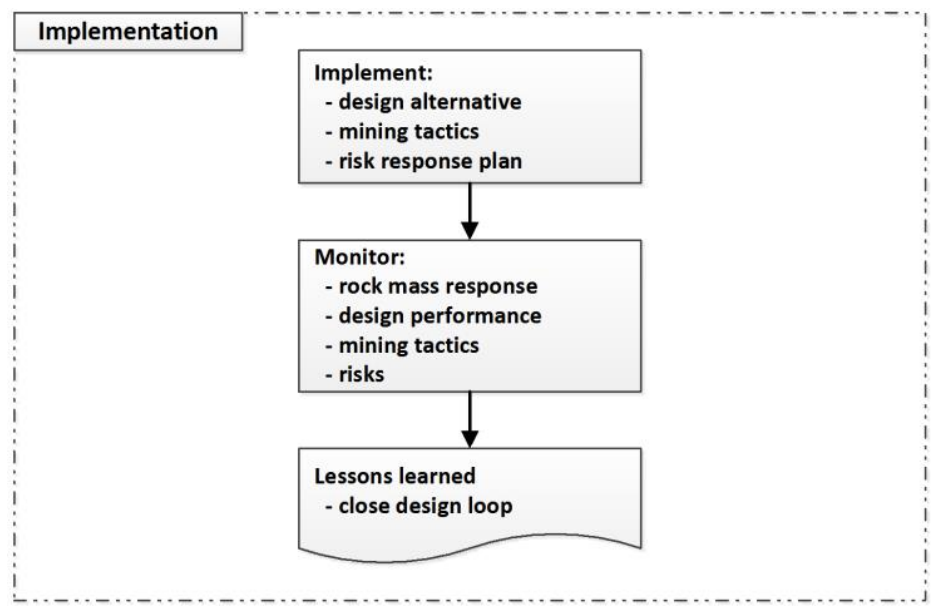

Figure 2 Objectives-based cave mining - implementation phase

\subsection{Geomechanics understanding}

Fundamental to deriving sound engineering solutions for cave mining designs, is a detailed understanding of the geomechanics mechanisms involved in cave mining; a geomechanics mechanism is defined as an observable occurrence that can be explained by physical causes.

Without such an understanding, how can solutions be derived to manage rock mass failure and the mechanisms responsible for initiating failure? Further, how can numerical models be properly calibrated without a detailed understanding of how the rock mass begins to fail and how that failure progresses, under changing and different conditions? Major geomechanics events and occurrences that demand an in-depth understanding for the successful operation of caving mines located in challenging environments include, among others:

- Rock mass failure (rockbursts) and the associated trigger mechanisms.

- Rock mass blasting.

- Hydraulic fracturing.

- De-stressing.

Given an understanding of the geomechanics mechanisms associated with the aforementioned events and occurrences, it is possible to consider how best to resolve significant cave mining problems (Table 1):

- Collapse of tunnels and pillars.

- Damaging mining seismicity.

- Major damage to infrastructure excavations. 
Table 1 Geomechanics mechanisms of mining problems

\begin{tabular}{|c|c|c|}
\hline Rock mass/problem & Geomechanics mechanism(s) & Description of impact \\
\hline \multirow{2}{*}{$\begin{array}{l}\text { Moderate } \\
\text { strength/tunnels } \\
\text { and crown pillar } \\
\text { collapse }\end{array}$} & $\begin{array}{l}\text { Rock blocks moving over weak joints - near } \\
\text { field and far field }\end{array}$ & $\begin{array}{l}\text { Pillar cracking } \\
\text { Tunnel roof and wall spalling }\end{array}$ \\
\hline & $\begin{array}{l}\text { Key blocks detaching from major geological } \\
\text { structures and subsequently loading the } \\
\text { crown pillar }\end{array}$ & $\begin{array}{l}\text { Major damage with floor heave } \\
\text { Excavation closure/pillar collapse }\end{array}$ \\
\hline \multirow{4}{*}{$\begin{array}{l}\text { High } \\
\text { strength/damaging } \\
\text { seismicity }\end{array}$} & \multirow{4}{*}{$\begin{array}{l}\text { Brittle rock mass failure - arising from } \\
\text { (Salamon 1983): } \\
\text { - } \quad \text { Rock mass on the threshold of unstable } \\
\text { equilibrium } \\
\text { - Changing stresses to initiate instability } \\
\text { - Sudden stress change at point of } \\
\text { instability to propagate shock waves } \\
\text { - Sources of seismic energy - (blasting } \\
\text { shock waves and stored strain energy) }\end{array}$} & $\begin{array}{l}\text { Tunnel onion skinning } \\
\text { Ejection of shards and blocks }\end{array}$ \\
\hline & & $\begin{array}{l}\text { Major excavation damage and } \\
\text { floor heave }\end{array}$ \\
\hline & & $\begin{array}{l}\text { Pillar shattering/excavation } \\
\text { closure }\end{array}$ \\
\hline & & \\
\hline
\end{tabular}

\subsection{Risk-based decision-making}

Linking the engineering and implementation phases, and essential to the selection process, is risk-based decision-making (Table 2).

Table 2 Decision support register - risk-based decision-making

\begin{tabular}{|c|c|}
\hline Factors & Information - results \\
\hline $\begin{array}{l}\text { Risks and hazards } \\
\text { identified }\end{array}$ & $\begin{array}{l}\text { Declaration of the risks and hazards identified from qualitative risk assessment, } \\
\text { with respect to the engineering, implementation and operational aspects of the } \\
\text { mining activity and project under analysis. }\end{array}$ \\
\hline \multirow[t]{2}{*}{$\begin{array}{l}\text { Risk severity } \\
\text { (consequence } \times \\
\text { probability) }\end{array}$} & $\begin{array}{l}\text { Qualitatively determine severity of the risks identified in order of importance, to } \\
\text { quantitatively appraise the most appropriate strategy to manage the risks, } \\
\text { a choice between avoidance (change design), mitigation (requires upfront } \\
\text { expenditure), and contingency planning (delayed expenditure should risk arise). }\end{array}$ \\
\hline & Monitor low severity risks, take action only when required. \\
\hline Economic impact & $\begin{array}{l}\text { Quantitative determination of the economic impact of different risk management } \\
\text { strategies for each alternative expressed in the cash flow analysis. }\end{array}$ \\
\hline Conclusions & With respect to the technical and risk appraisal work. \\
\hline Recommendations & With respect to the technical and risk appraisal work. \\
\hline Selection & Select design alternative - from technical and risk viewpoints. \\
\hline Risk response plan & $\begin{array}{l}\text { Plan to monitor and manage risks, identifying risk management strategies and } \\
\text { management responsible for their implementation and supervision. }\end{array}$ \\
\hline
\end{tabular}

No cave mining operation is without risk, and it is essential to assess when risks are likely to occur, the severity of each risk, the duration - and consequently, which risk management strategy is likely to be most cost effective. Pre-feasibility studies are the most appropriate phase of project development to select the most appropriate engineering design alternative - to technically and financially support the selection process, and prior to spending significantly greater sums on engineering during the feasibility study. 
Many risks involved in cave mining are well known, and as a matter of course, most cave mining engineering designs attempt to mitigate risks. However, not all design work approaches the management of risk in a formal manner to filter out low severity risks by qualitative appraisal, in order that a more rigorous quantitative assessment of the moderate to high severity risks can be made to select the most appropriate alternative.

Quantitative risk analysis is performed to determine the economic impact of the risk management strategies required to manage risks attached to the alternative designs, to aid the decision-making process, taking into account both technical and risk appraisal results.

Having selected the most appropriate alternative, based upon the conclusions and recommendations made as a result of the technical and risk appraisal work, a risk response plan (or register) is drawn up to monitor and manage risks over the course of the engineering, project implementation and ongoing operations (Table 2).

\subsection{Implementation}

Engineering design work requires feedback from the objectives-based monitoring program of the implementation phase, in order to secure the ongoing improvements necessary to survive and prosper in the global market place of today (Figure 2). How to integrate the lessons learned is an essential protocol for companies to develop and apply, to make use of the analysis developed from the measurements and observations made during the monitoring program.

\section{RENO mine extraction sequence}

The selection of a mine extraction plan for RENO, a major sector within the El Teniente mine, serves as an example of the alternative selection and implementation process. Application of the methodology to this engineering task lead to an early and successful conclusion to the engineering design phase of the work. More importantly, the implementation phase of the work was also successful, in what had previously been a most intractable mining sector, suffering a number of major mining-induced, damaging seismicity incidents. There is little doubt of the impact of the methodology, which lead to the sector achieving daily rates of production not previously achieved. The sector continues today to provide a major contribution to the 131,000 tpd output of the El Teniente mine. However, it is acknowledged that without the enthusiastic work of the El Teniente engineering team and the operations management and workforce, a different outcome may well have occurred in the implementation phase. Of course, some would argue that hydraulic fracturing might well have made the greatest contribution. Changing the mining method alternative, from advanced undercutting to conventional panel caving with hydraulic fracturing during the course of the mine plan, is also considered to have been instrumental for the success finally achieved in the RENO mine.

\subsection{Engineering tasks}

The main steps of the engineering task are outlined hereunder, including implementation which concludes this section illustrating application of the methodology. A major objective of the RENO sector work was to close the engineering design loop for the key design criteria, parameters and operational risks facing the El Teniente mine at that time:

- Identification of the key design criteria and parameters, and key operational risks.

- Calibration of these criteria, parameters and risks with past performance data from across Division El Teniente, to generate geotechnical zone failure curves, for the prediction of rock mass response to designs and associated mining plans.

- Subsequently monitor these criteria (Figure 2), parameters and risks in current (and future) mining sectors in order to confirm the failure curves developed. 
The steps involved in closing the engineering design loop, were perceived, at that time, to involve:

1. Mining design process incorporating information and knowledge of:

a. Geological information and history.

b. Geotechnical characteristics and classifications.

c. Field stresses.

d. Geotechnical dominions and behavioural zones.

e. Analysis and selection of design criteria and parameters for specific mining environments.

f. Engineering analysis of 3D production level and mine extraction sequence layouts (based upon associated time steps illustrating how excavations are formed in time).

g. Specification of ground support systems.

h. Re-analysis of production level and mine extraction sequence layouts to confirm support selection.

i. Risk-based decision-making.

2. Implementation plan to show how best to achieve the design in practice:

a. Set of operational rules based upon the engineering analysis and previous experience.

b. Management of seismicity.

c. Demanding the selection of equipment and resources to implement the plan.

d. To develop a Gantt chart based upon the evolution of the mining plan showing steps in 3D and over time.

e. Simulation confirmation of plan logistics and interference control.

3. Monitoring program focused upon measurements and observations of the:

a. Design criteria and parameters.

b. Associated operational risks.

c. Requiring the specification of instruments, systems and time periods.

d. Analysis of measurements and observations such as seismic monitoring, extensometers and field observations, to develop conclusions with respect to the response of the rock mass to specific mining steps.

4. Closure of the engineering design loop:

a. based upon analytical conclusions from the monitoring program; in order to

b. close the engineering design loop and thereby improve the design; with

c. subsequent application to current mining sectors and future mining projects.

\subsection{Extraction plan alternatives}

Four mining plan alternatives were considered, inclusive of the official mining plan:

1. PND 2008 - official mining plan, taken as the base case (Figure 3).

2. South to north advancing cave-front.

3. East to west advancing cave-front.

4. Southeast to northeast. 


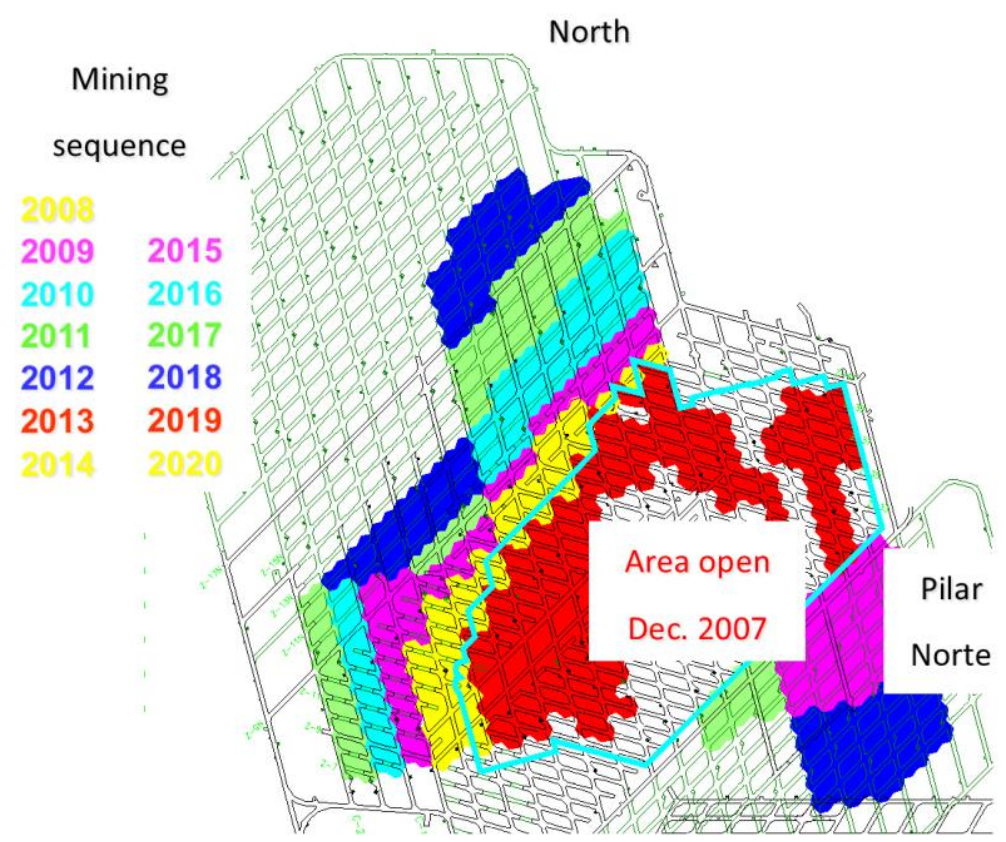

Figure 3 RENO mining plan 2008 to 2012 (courtesy El Teniente)

Developing the alternative mining plans encompassed the following constraints:

- A management requirement to maintain the production goals of the official plan.

- The original mining plan sequence, which was based upon a single front, and of course the mine infrastructure to service the original sequence would demand significant time to modify for any significant changes to the plan.

- The magnitude of events recorded at that time of mining-induced seismicity associated with the advance of the hanging wall caving front.

- The occurrence of collapses within the production complex and the existence of design weaknesses in the production level which concentrated stresses.

- The need to implement narrow caving fronts to manage the level of abutment stresses experienced mainly in the east of the sector.

Planning strategy incorporated the following parameters:

- Cave-fronts less than $150 \mathrm{~m}$ in length to be applied.

- Caving sub-fronts to be at least $80 \mathrm{~m}$ out of phase.

- Implementation of panel caving with advanced undercutting.

- Cave-front to advance at a favourable angle to major structures.

- Reduced incorporation and recovery rates applied to the central part of the cave-front and to breccia lithologies.

The various alternative mining plans had to synchronise with the five year mining plan for the adjoining northern mining sectors (Figure 4). 


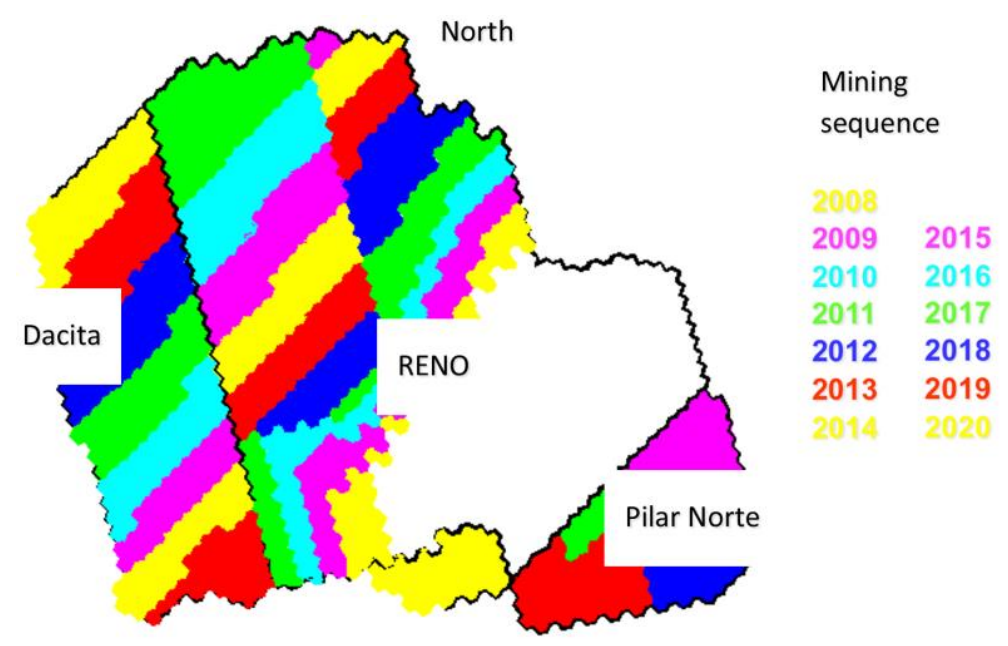

Figure 4 North mine plan - 2008 to 2020 (courtesy El Teniente)

\subsection{Engineering and risk analyses}

Given that the management of stress is the overriding concern with respect to selecting an alternative sequence for a mining plan, the engineering work involved numerical modelling and associated risk analyses of the different sequences.

Calibration of MAP3D boundary element modelling, based upon subjective observations in the field, considered all the seismic events registered in the rock mass surrounding RENO over the period from November 2007 to June 2008 (Figure 5). Based upon a calibration of stress magnitudes versus observations of damage in the mine, comparison of the induced stresses developed by the various plan alternatives was performed and considered together with qualitative analyses of the risks of each alternative over the years of each alternative (Table 3 and Figure 6).

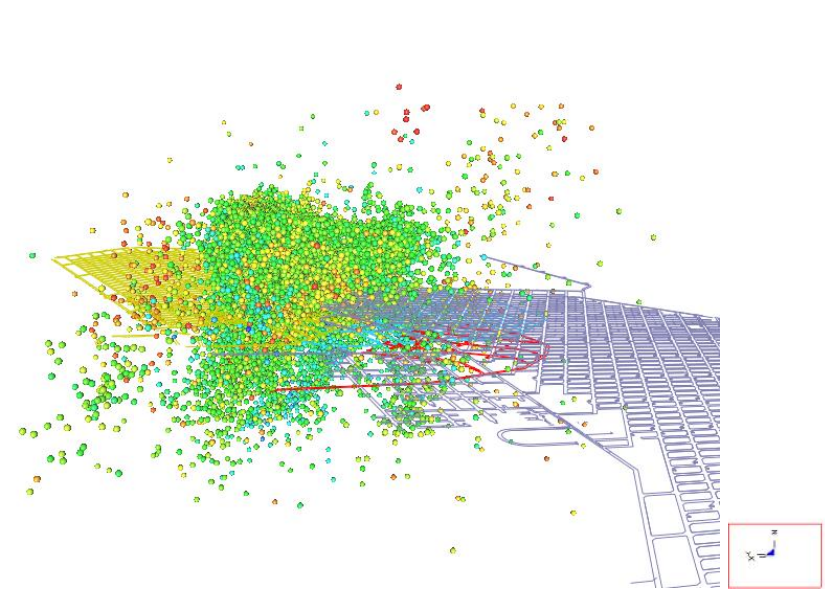

(a)

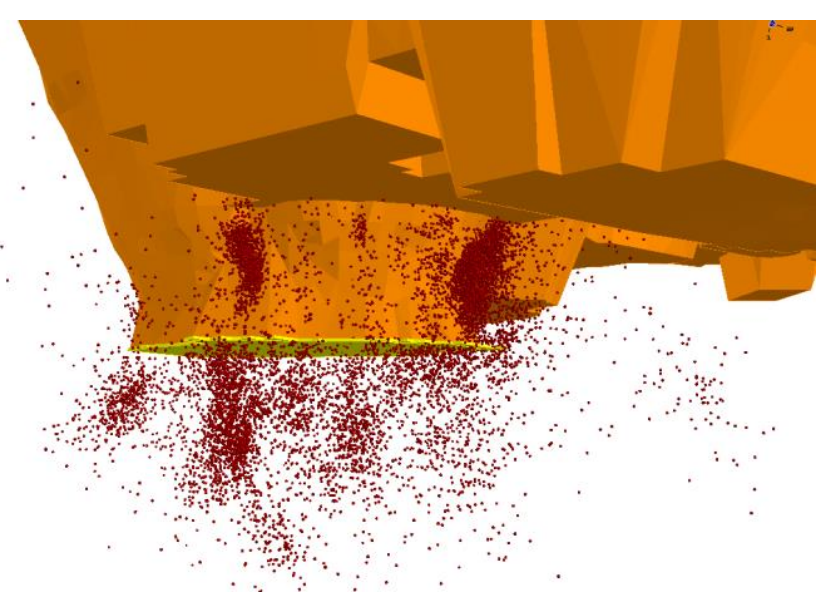

(b)

Figure 5 Seismicity 2007 to 2008 - RENO (courtesy El Teniente); (a) Hanging wall seismicity; (b) Sector seismicity 
Table 3 Qualitative appraisal - core mining and geomechanics risks

\begin{tabular}{|c|c|c|c|}
\hline Hazard & Causes & Major effects/consequences & Mitigation \\
\hline $\begin{array}{l}\text { Rockbursts } \\
\text { Risk severity } 7\end{array}$ & $\begin{array}{l}\text { Undercutting } \\
\text { Ore draw } \\
\text { Rate of undercutting } \\
\text { Rate of draw } \\
\text { Blasting weight } \\
\text { Basic assumptions } \\
\text { Geometry } \\
\text { Environment } \\
\text { Singularities/contacts } \\
\text { Faults }\end{array}$ & $\begin{array}{l}\text { Fatalities } \\
\text { Loss of productive capacity } \\
\text { Replacement of productive } \\
\text { area } \\
\text { Degradation of rock mass } \\
\text { Repair work and costs }\end{array}$ & $\begin{array}{l}\text { Pre-conditioning } \\
\text { Narrow fronts } \\
\text { Slow mining rate } \\
\text { Controlled blasting }\end{array}$ \\
\hline $\begin{array}{l}\text { Collapses } \\
\text { Risk severity } 7\end{array}$ & $\begin{array}{l}\text { Major structures } \\
\text { Rate of draw } \\
\text { Rockburst damage } \\
\text { Remnant pillars } \\
\text { Key blocks } \\
\text { Environment } \\
\text { Singularities/contacts } \\
\text { Faults }\end{array}$ & $\begin{array}{l}\text { Loss of productive capacity } \\
\text { Replacement of productive } \\
\text { area } \\
\text { Degradation of rock mass } \\
\text { Repair work and costs }\end{array}$ & $\begin{array}{l}\text { Pre-conditioning } \\
\text { Narrow fronts } \\
\text { Controlled blasting }\end{array}$ \\
\hline $\begin{array}{l}\text { Mud/water } \\
\text { rushes } \\
\text { Risk severity } 6\end{array}$ & $\begin{array}{l}\text { Surface water } \\
\text { Ore draw }\end{array}$ & $\begin{array}{l}\text { Fatalities } \\
\text { Loss of productive capacity }\end{array}$ & $\begin{array}{l}\text { Draw control } \\
\text { management }\end{array}$ \\
\hline $\begin{array}{l}\text { Implementation } \\
\text { Risk severity } 6\end{array}$ & $\begin{array}{l}\text { Production pressures } \\
\text { Understanding } \\
\text { Undercutting } \\
\text { Draw } \\
\text { Blasting }\end{array}$ & $\begin{array}{l}\text { Rockbursts } \\
\text { Collapses } \\
\text { Delay and loss of productive } \\
\text { capacity } \\
\text { Replacement of area }\end{array}$ & $\begin{array}{l}\text { Education } \\
\text { Training } \\
\text { Supervision } \\
\text { Controlled blasting }\end{array}$ \\
\hline $\begin{array}{l}\text { Transition zone } \\
\text { Risk severity } 4\end{array}$ & Undercutting & Repair work and costs & $\begin{array}{l}\text { Implementation plan } \\
\text { Support design }\end{array}$ \\
\hline $\begin{array}{l}\text { Coarse } \\
\text { fragmentation } \\
\text { Risk severity } 4\end{array}$ & $\begin{array}{l}\text { Rock mass } \\
\text { characteristics } \\
\text { Low stresses }\end{array}$ & $\begin{array}{l}\text { Reduction in productivity } \\
\text { Repair work and costs }\end{array}$ & $\begin{array}{l}\text { Sub-level longhole } \\
\text { blasting } \\
\text { Dynamic weakening } \\
\text { with explosives (DDE) }\end{array}$ \\
\hline $\begin{array}{l}\text { Dilution } \\
\text { Risk severity } 4\end{array}$ & Ore draw & Loss of reserves and revenue & $\begin{array}{l}\text { Draw control } \\
\text { management }\end{array}$ \\
\hline $\begin{array}{l}\text { Poor caving } \\
\text { propagation } \\
\text { Risk severity } 3\end{array}$ & $\begin{array}{l}\text { Insufficient cave area } \\
\text { Low fracture } \\
\text { frequency }\end{array}$ & $\begin{array}{l}\text { Delay in generating } \\
\text { productive capacity }\end{array}$ & Pre-conditioning \\
\hline
\end{tabular}




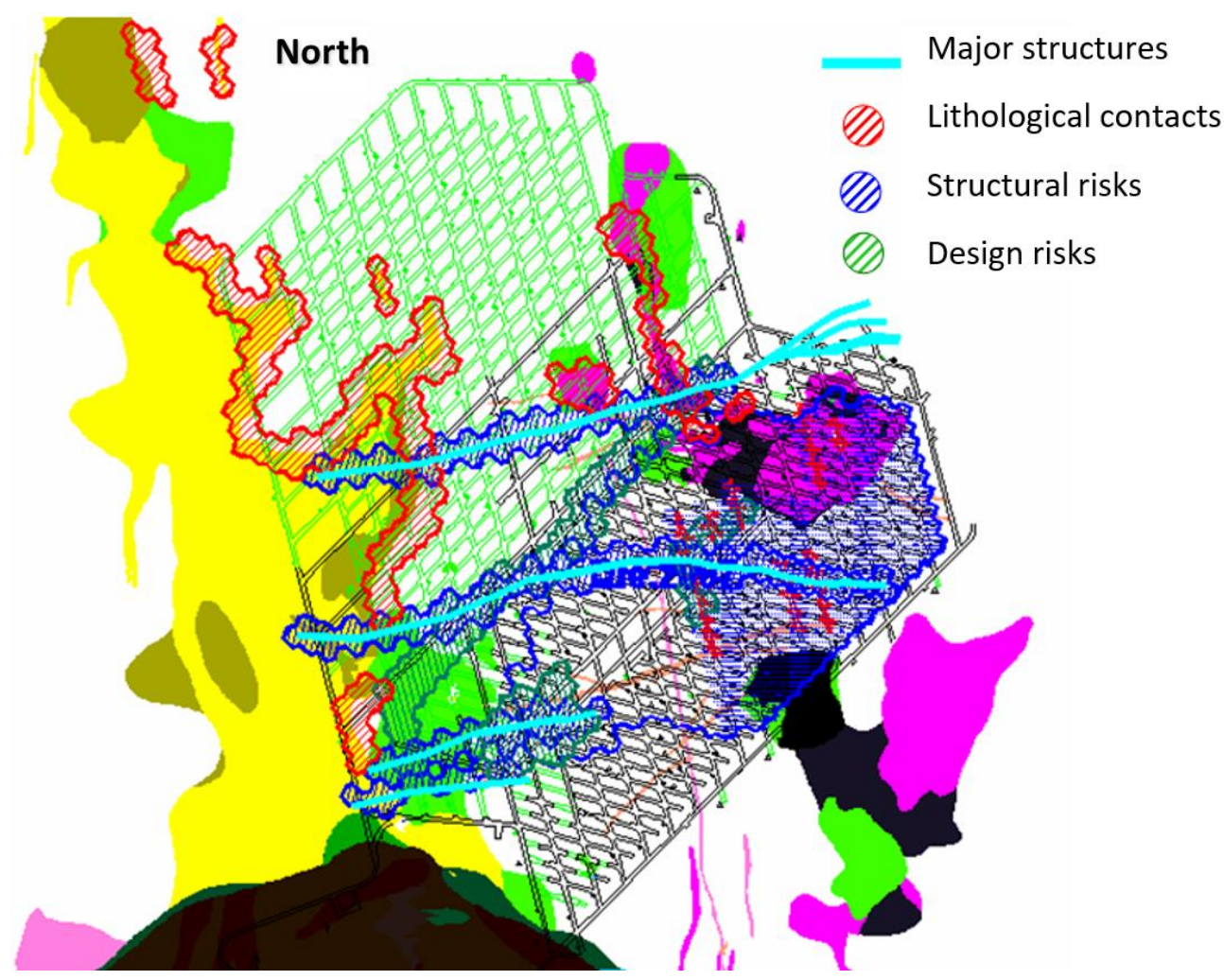

Figure 6 Severe risks locations plan - RENO (courtesy El Teniente)

\subsection{Extraction sequence selected}

A quantitative risk assessment had been planned as part of the engineering work, to aid the selection of a mining plan. However, the engineering work was completed following the completion of qualitative risk assessment work, and the selection made of a modified version of the official mining plan. In the event, it was not possible to generate mining plans with significantly distinct differences to the 'unique caving front' approach applied over many years, owing to the restrictions that the underlying materials handling and infrastructure systems imposed. Nevertheless, the mining plan alternative that was developed was sufficiently different, and was considered, at that time, to be capable of providing a basis for the operations workforce and management to implement in the coming months and years. This proved to be the case, with the implementation carried out by outstanding operational and technical teams, working under very difficult field stresses. Whereas the methodology put forward in this paper requires the application of quantitative risk-based analysis, in the real world, it is acknowledged that sometimes time constraints will limit the selection process to qualitative risk analysis. A risk register is an important deliverable of qualitative risk analysis, and in this case is embodied in Figure 6, which was used as a risk management tool going forward in the extraction of the mine reserves.

\subsection{Implementation - current mining}

In the event, the RENO sector became a stable and successful mining sector, today contributing some 40,000 tpd to the division's production call. Success in the sector is considered to be associated with:

- Implementation of conventional panel caving (14 m high undercut ring blasts).

- Together with the application of hydraulic fracturing ahead of the caving front.

- Strictly following the geomechanics guidelines to manage the face advance and cave-back.

Accordingly, today the RENO-Dacita sector successfully manages a caving front some $800 \mathrm{~m}$ in length, a dimension previously thought impossible to achieve. 


\section{$4 \quad$ Hydraulic fracturing}

Following on from the conclusion concerning the application of hydraulic fracturing within the RENO-Dacita sector (Section 3.5), the hydraulic fracturing methodology is considered to have had a very beneficial impact of upon:

- Management of abutment loading seismicity.

- Promoting cave initiation.

- Propagation of the cave-back breakthrough.

- Fragmentation reduction.

- Limiting the dimensions of unstable key blocks.

\subsection{Design objectives - hydraulic fracturing}

Originally, Codelco studied the application of hydraulic fracturing in the Andina and El Salvador cave mines to examine whether fragmentation could be improved. Investigation in the Diablo Regimiento sector of El Teniente, was carried out to study the impact of hydraulic fracturing upon cave initiation, cave propagation and cave breakthrough, which lead to the discovery of the impact upon mining-induced seismicity. Undertaking the investigation in the Diablo Regimiento mine is a good example of the successful application of the risk-based decision-making design process advocated herein - from design to implementation. Today, the reduction of the magnitude of microseismic events induced by mining activity is seen as the principal objective. This begs the question as to what knowledge is available to demonstrate the mechanism by which microseismic activity is changed by hydraulic fracturing. Is the same design applicable to both fragmentation and seismicity objectives? Precisely how do new fractures introduced into a rock mass improve fragmentation? Similarly, how does hydraulic fracturing specifically improve the rate of propagation of the cave-back? Today, the answer to such questions remains difficult to make, although recent investigations and analyses of mining-induced seismicity within El Teniente and of the dimensions of rock blocks reporting to drawpoints, provide some answers, which are discussed in the following section. In addition, developments elsewhere have made it possible to monitor in detail, in a precise manner, the configuration of hydraulic fracturing within different environments.

The standard application of hydraulic fracturing within Division El Teniente comprises HQ diameter boreholes with a spacing between fractures of $1.5 \mathrm{~m}$ and drilled on a $40 \times 40 \mathrm{~m}$ drilling grid.

\subsection{Geomechanics mechanism - hydraulic fracturing}

Considerable argument and discussion has taken place within the division's geoscientific and professional workforce, concerning the need for specific hydraulic fracturing designs for each application. Positions range from "why change something that works?" to "it is simply not logical to apply the same design to rock masses that are clearly different and to locations that vary from close to a caving front to remote from mining activities". Further, the current standard design has no basis for fractures to be spaced $1.5 \mathrm{~m}$ apart, other than that the packers cannot be placed physically closer. Availability of NQ diameter boreholes will allow fractures to be spaced $1 \mathrm{~m}$ apart. Thus opening up the issue of design, smaller diameter boreholes will cost less and be faster to drill, all things being equal - an important matter for the mine to remain competitive. Hydraulic fracturing also impacts the mine development and construction program, considerably extending the preparation time, so demanding a better understanding of the hydraulic fracturing process.

Division El Teniente recently commissioned an in-depth review of the database of mining-induced microseismic activity, which concluded that hydraulic fracturing modifies the rock mass, in such a way as to cause the diffusion of high field stresses away from the modified rock mass (Dunlop \& Blanco 2017). Further, analysis of microseismic activity induced by a hydraulic fracturing program to protect the 
development and construction of major infrastructure tunnels, indicated that microseismic activity occurs some distance from, but enveloping the hydraulic fractures developed. It thus is apparent that a volume of modified rock mass enveloping the fractures is created, in addition to the fracture. Such an observation suggests that in addition to the assumed $20 \mathrm{~m}$ radius fracture produced by hydraulic means, an ellipsoid volume per fracture may well be the best design parameter. In any event, the assumption of a $20 \mathrm{~m}$ radius fracture, regardless of the stress field, rock mass and location of the fracturing borehole in relation to cave mining is questionable and needs to be tested.

A geophysical tool developed in the early part of this century combines acoustic emission (AE) sensors and the hydraulic fracturing unit together (Manthei et al. 2003), which can be operated from within a single borehole (Figure 7). Enhanced sensitivity to seismicity is achieved with the new tool, owing to the closeness of the sensors to the fractures generated (Zang et al. 2016).

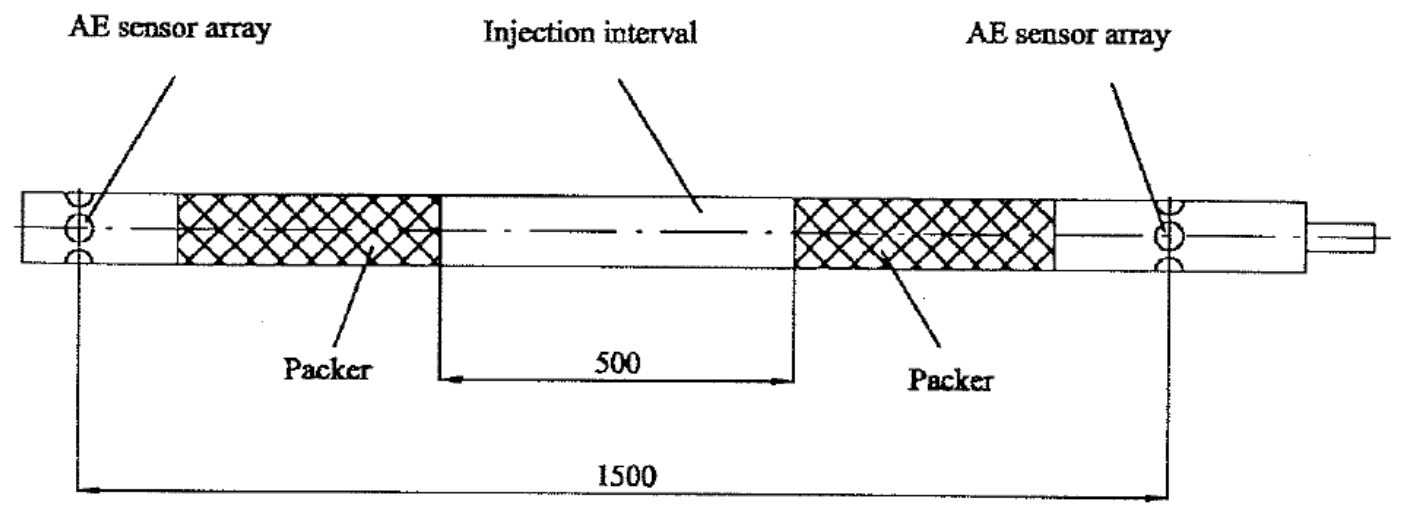

Figure 7 Hydraulic fracturing tool (Manthei et al. 2003)

Results from the tool clearly demonstrate the extent and configuration of a hydraulic fracture, and the shape and dimension of the volume of rock mass enveloping the hydraulic fracture (Figure 8).

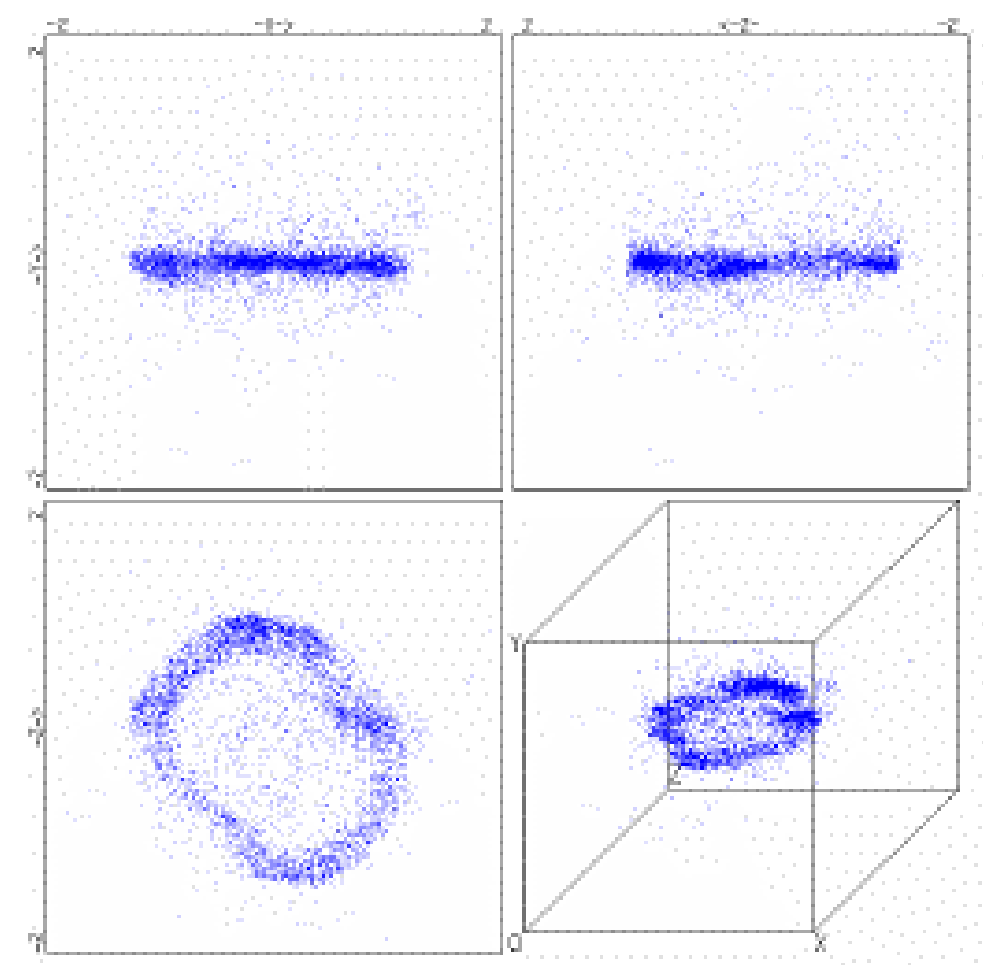

Figure 8 Hydraulic fracturing seismicity (Manthei et al. 2011) 
For example, the plan view indicates that the field stresses govern the plane shape of the fracture, which is more rectangular than circular - assuming that the salt rock mass is homogenous in the vicinity of the borehole. Given such clarity, this borehole tool should be able to quickly establish, within specific rock mass and stress environments, the extent and configuration of hydraulic fractures - to aid the derivation of specific designs for individual environments. Future designs of hydraulic caving may thus be based upon in situ measurements to specify the spacing between fractures and the drilling mesh (related to the plane shape of the fractures). The measurements would also give technical support to fulfilling design objectives, for example: what fracture spacing is needed to improve fragmentation?, what volume of rock mass modified by micro-fractures is sufficient to manage mining-induced seismicity ahead of the cave mining front?, and so on.

Division El Teniente, is of course planning various tests to improve the knowledge of the hydraulic fracturing process.

Finally, it has been shown, from drawpoint observations, records of interruptions to the draw of ore that hydraulic fracturing unquestionably improves fragmentation of the rock mass - the original design objective (Brzovic 2016). Further, Brzovic found, from measurements of the rock blocks reporting to, and hanging up drawpoints, that there is a fundamental relationship between the thickness and length of rock blocks emerging from the caving column, in the ratio of $1: 2$. That is to say that a thickness of $1 \mathrm{~m}$ is associated with a block $2 \mathrm{~m}$ in length. Thus, hydraulic fractures $1.5 \mathrm{~m}$ apart will produce rock blocks $3 \mathrm{~m}$ in length. If fragmentation is the principal design objective, it might well be worthwhile drilling NQ boreholes to produce fractures spaced $1 \mathrm{~m}$ apart. However, the findings of Pariseau (1983) indicate that even blocks with $2 \mathrm{~m}$ lengths will almost certainly cause drawpoints to hang-up (Table 4).

Table 4 Relative interlocking frequency problems

\begin{tabular}{ll}
\hline Dimension ratio & Relative interlocking frequency \\
\hline$D / d$ or $D_{0} / d>5$ & Very low, almost certain flow \\
$3<D / d$ or $D_{0} / d<5$ & Often, flow uncertain \\
$D / d$ or $D_{\circ} / d<3$ & Very high, almost certain no-flow \\
\hline
\end{tabular}

where:
$\mathrm{D}=$ ore pass diameter.
$D_{0} \quad=$ draw point (outlet) diameter.
$\mathrm{d} \quad=$ maximum size of muck.

In the case of rock fragments that are slab-shaped rather than equi-dimensional, a very conservative approach would be to use the largest dimension of the fragments as $d$.

\section{Conclusion}

Cave mining design methodology as put forward in this paper is based upon the fundamental precepts that: a detailed and in-depth knowledge and understanding of the geomechanics mechanisms involved in the response of the rock mass to the creation of excavations by mining is essential; selection of alternative design components is based upon quantitative risk analyses integrated within project cash flows; successful implementation of mining designs requires that operators follow method-specific mining tactics. Successful outcomes however, require that the workforce understands and takes ownership of the concepts, as the miners, engineers and geologists of the RENO sector demonstrated. 


\section{Acknowledgement}

Objectives-based cave-based mining design practice has been developed from the shared work experiences of Gavin Ferguson and Marko Didyk reviewing the work of others for Codelco, but principally within the extraordinary copper porphyry deposit known as El Teniente and working together with the many engineers and managers who have worked in the division since 1990. It is not possible to mention the many, but it would be wrong to omit Octavio Araneda, Eduardo Rojas, Andres Brzovic, Cesar Pardo, Mauricio Larrain and Patricio Cavieres.

\section{References}

Box, GEP 1979, 'Robustness in the strategy of scientific model building', in RL Launer \& GN Wilkinson (eds), Robustness in Statistics, Academic Press, New York, pp. 201-236.

Brzovic, A 2016, Fracturamiento hidráulico para la gestión de la fragmentación de la roca primaria en mina el Teniente, GRMD-SGL-INF-0038-2016, Codelco Chile, Rancagua.

Dunlop, R \& Blanco, B 2017, Sismicidad inducida TAP OIM PNNM, Nota Interna T11M408-I1-T11M408-06831-NOTGE04-6830-039, Codelco Chile, Rancagua.

Ferguson, GA 2015, Evolution of a design methodology for use in cave mines developed in challenging geomechanics environments, unpublished PhD thesis, The University of Leeds, Leeds.

Manthei, G, Philipp, J \& Eisenblätter, J 2011 'Acoustic emission measurements in rock structures and on rock specimens', memorandum from DGG Kolloquium Induzierte Seismizität, 23 February 2011, special issue 1/2011 viewed 3 July 2017, https://dgg-online.de/WordPress_01/wp-content/uploads/2016/04/DGG2011_Induzierte_Seismizitaet.pdf

Manthei G, Eisenblätter, J \& Kamlot P 2003, 'Stress measurements in salt mines using a special hydraulic fracturing borehole tool', in O Natau, E Fecker \& E Pimentel (eds), Geotechnical Measurements and Modelling 2003 Swets \& Zeitlinger, Lisse, pp. 355-360.

Pariseau WG 1983, 'Rock flow in ore passes', Guidelines for Open-pit Ore Pass Design, vol. 1 - final report, Engineers International, Inc., viewed 3 July 2017, http://www.onemine.org/document/document.cfm?docid=200254, 259 pp.

Salamon, MDG 1983, 'Rockburst hazard and the fight for its alleviation in South African Gold Mines', in IW Farmer (ed), Proceedings of Rockbursts: Prediction and Control, Institution of Mining and Metallurgy, London, pp. 11-36.

Zang, A, Stephansson, O, Stenberg, L, Plenkers, K, Specht, S, Milkereit, C, Schill, E, Kwiatek, G, Dresen, G, Zimmermann, G, Dahm, T \& Weber, M 2016, 'Hydraulic fracture monitoring in hard rock at $410 \mathrm{~m}$ depth with an advanced fluid-injection protocol and extensive sensor array', Geophysical Journal International, vol. 208, no. 2, pp. 790-813. 